\title{
Education à l'image and Medienkompetenz: On the discourses and practices of film education in France and Germany
}

\author{
Bettina Henzler* - University of Bremen, Germany \\ First published in Mise au point (Henzler, 2015) \\ Translated from the French by Madeline Whittle \\ and updated by the author
}

\begin{abstract}
This article compares the discourses, practices and politics of film education in France and Germany, and outlines their historical development. The discourses on film education in the two countries are fundamentally different: whereas German film education is anchored in the global politics of media education and around notions of Medienkompetenz (media competence), cinema in France is a field of art education centred on the transmission du cinéma (film mediation) or l'éducation artistique (art mediation). While the first initiatives in film education in both countries date back to the beginning of the twentieth century, this article explores how they developed in significantly different ways. In France, the establishment of film education was promoted and influenced by the culture of cinephilia, which imposed the notion of film as an art form. In Germany, film education - after having been pushed by the Nazi regime - suffered for a long time from sceptical attitudes towards the media and their ideological impact, and was formed by the critical approach of the Frankfurt School. This article details how history and the 'state of the art' of film education are interlinked with the different discourses and cultures of cinema in both countries, as well as the extent to which present political and educational practices draw upon long-standing historical and cultural traditions. In doing so, this article contributes to reflections upon film education at a wider European or international level, where similar debates around film or media literacy are taking place.
\end{abstract}

Keywords: film; education; media; history; Germany; France

\section{Introduction}

If we compare the state of affairs around film education in schools in France and Germany, the differences are quite apparent, whether in terms of scale and institutional support (related to funding), approaches and methods, or discourse.

Film education in Germany is inscribed in a more general policy of media education, whereas in France cinema is a component of arts education. Thus the discourses about film education hinge on the key concepts of Medienkompetenz and Medienbildung (media literacy and media education) in Germany, and l'éducation à l'image (visual literacy education, or, translated literally, 'education towards the image') in France. These paradigms reflect different political strategies and pedagogical 
approaches, as well as the different cultural traditions of which they are a product. If, in both countries, the first steps in film education date back to the beginning of the twentieth century, their subsequent developments have followed very different paths. In France, the establishment of film education was influenced by the culture of cinephilia, which promoted the notion of cinema as an art form, while in Germany, media education was influenced by the ideological critiques of the Frankfurt School and an attitude of mistrust with regard to the ideological function of cinema as mass media. Thus, both the history and the current state of film education are connected to cultural traditions and, above all, to the different cinematic discourses in the two countries - a fact that demonstrates the important influence of cultural traditions on political and educational realities today.

Whereas film education in France has already been the subject of historiographical research examining its discourses, practices and institutions (Desbarats, 2002; Boutin, 2010), the history of film education in Germany is still awaiting a deep and systematic study. In particular, there is an abundance of articles on the history of media pedagogy that describe the origins of principal concepts, without accounting for the specific discourses and practices of film education and mediation. I will therefore attempt to compare the major avenues along which discourses and practices have developed historically, and to emphasize several exemplary analyses. In so doing, I will formulate hypotheses that can help to open up spaces for reflection and research, without claiming to tackle those tasks in an exhaustive or generalized way. It must also be pointed out that my description of developments in Germany after the war will largely be limited to West Germany, the birthplace of the discourses that are dominant today. The history of film education under socialist dictatorship would require an entire chapter of its own.

\section{Discourse: Cinema and the audiovisual}

To evoke quickly the different paradigms present in the current discourses on film education in France and Germany, I will start with a comparison between official reports on the subject, published on the websites of the French Ministère de l'Éducation nationale (EN) and the German Kultusministerkonferenz (KMK).

The differences are already evident in these institutions themselves: while the EN is a centralized institution, responsible for school instruction across France, the KMK brings together the ministries of education and culture in Germany, where education is the exclusive domain of the federal state governments (Bundesländer). The reports from these bodies thus serve different functions: whereas the EN website describes already-existing strategies and structures, the KMK offers recommendations for the developments to be carried out by regional governments. Thus, if there exist a variety of educational policies in the different German states, we can nonetheless take this report - the product of an agreement between the different state/local ministries as representative of a national strategy and (most importantly for our purposes) of a national political discourse on the subject.

The first observation concerns the relationship between cinema and media. On the EN website, there is a very pronounced distinction made between 'cinema' and 'media': one page is dedicated to 'L'éducation à l'image, au cinéma, et à l'audiovisuel' ('Visual, Cinematic, and Audiovisual Education'), where the title itself designates a central role for 'cinema', encouraging a cultural and artistic approach (Ministère de I'Éducation nationale, 2017). Regarding 'Education \& Media: Understanding and Deciphering Audiovisual Media', there is only a recent report that links to a website run by the Conseil supérieure de l'audiovisuel. The latter site notes a 'convergence among 
audiovisual media', and deals mainly with television and digital media (Ministère de l'Éducation nationale, 2014). The same assessment can also be found in the report posted on the KMK website, which foregrounds the acquisition of Medienkompetenz (media literacy) through Medienbildung (media education) (KMK, 2012: 3). In this tenpage text, film education (Filmbildung) is mentioned only once (in one sentence), in the context of fostering aesthetic and cultural awareness. Here too, then, cinema is represented as an aesthetic experience, but this is clearly subordinated within a generalized education in media. And furthermore, the cinema-art connection becomes ambiguous when one consults the report, posted on the same website, concerning the 2007 cultural policy action that mentions (over ten pages) theatre, musical performance, libraries, museums and sociocultural centres, but not cinema (KMK, 2013). This very explicitly demonstrates a cultural difference, namely that in France the cinema is institutionalized as an art, while in Germany - even if there exist a variety of film-education practices including aesthetic approaches - cinema is largely regarded as a form of mass media in official discourses and practices.

The second observation concerns the pedagogical objectives that are reflected in the key concepts of l'éducation à l'image and Medienbildung and Medienkompetenz. L'éducation à l'image is a transitive notion that is focused on the objectbeing transmitted: the image (cinematic and audiovisual). Medienbildung and Medienkompetenz are compound words that describe a subject to be trained: the student. Medienbildung refers to the training of any individual through mediated experiences (whether at school or elsewhere); Mediakompetenz designates the individual's specific proficiency in using the media. This difference between the terms éducation and Bildung reflects, as per Ernst-Ulrich Große, a difference in general educational traditions. " But, in our context, it is especially revealing of differences in the pedagogical approaches to cinema. Whereas, on the EN website, cinema and audiovisual media are described as expressions of 'a culture' that is worthy of (and that requires) a dedicated course of study, ${ }^{2}$ in the KMK's report, media are instead represented as an instrument, whether with a didactic function or for purposes of shaping a social actor. ${ }^{3}$ Furthermore, the concept of l'image points to a formal definition: imagery, including photography, film and video games. The concept of media, on the other hand, is aimed at a technical (and rather arbitrary) definition: technologies of communication, which include newspapers, radio, databases and so on.

This distinction implies a more broadly historical vision on the EN website including, notably, the teaching of 'traditional techniques' and 'the history of the arts'. In contrast, the German report concentrates on topicality: on the capacity to act and to communicate in contemporary society. The distinction also corresponds to a more positive - that is, more cinephiliac - attitude on the part of the French, and a more sceptical and critical attitude on the part of the Germans, who preach 'constructive and critical engagement with the media world' ('konstruktive und kritische Auseinandersetzung mit der Medienwelt', KMK, 2012: 3) - implicitly referring to new media. One wants to provide access to something unknown and different, the other wants to help develop mastery over access to something already known. Lastly, this contrast likewise expresses a political conception of Medienbildung on the German side, whose primary objective is explicitly civic education, politische Bildung (KMK, 2012: 4-5), as an opportunity for political, social and cultural involvement. And even if, in the French report, the section covering artistic and cultural education also draws on the central premise of 'democratization and equality of opportunity', here this is achieved, instead, through the ideal of access to culture for all (Ministère de I'Éducation nationale, 2018). 
In the interest of being concise, I briefly call attention to the outlines of the arguments. There are also detailed parallels, notably in the proposed methods of combining analytic and creative practices. However, my intention is to highlight certain tendencies and dominant ideological stakes in the official discourses, which will later be analysed according to historical and practical dimensions and impact. These documents reveal the major principles of cinema education that have been developed in both countries over time. In France, these include semiotics (the image as 'complex language'), cinephilia (the image as 'culture') and the visual arts (the image as 'artistic practice') (Desbarats, 2002: 459). In Germany, they consist of utilitarian approaches, ranging from Mediendidaktik (using media as teaching aids, KMK, 2012: 4) to handlungsorientierte Medienpädagogik (using media as a communication tool, ibid.: 4-5); and critical approaches, between Bewahrpädagogik (protection against the media, ibid.: 6) and Medienkritik (ideological critique of the media, ibid.: 5-6) (Schorb, 1995: 50-2).

\section{History: Cinephilia and ideological critique}

The development of these different discourses around film education is tied to complex historical and cultural differences that cannot be addressed here. I have already alluded to differences in the schooling systems and educational traditions of France and Germany, but we should also mention differences in cultural traditions and policies, as well as differences in cinema's symbolic, social and economic status. Here I will focus on the concrete link between cinema and pedagogy, and will invoke - as a hypothesis - three central aspects contributing to the different development of film education in the two countries: the relationship of education and culture with/ to cinema; the institutionalization of film education by the state; and the role of civic movements.

\section{The relationship of education and culture with/to cinema}

The relationship of cinema to education was already taking shape at the beginning of the twentieth century. In the beginning, the same debates around cinema were unfolding in educational circles in both France and Germany, corresponding to the debates that have surrounded the image more generally - regarded as a threat or as a means of instruction - since ancient Greece (Boutin, 2010: 126-37). Cinema, as a new mass medium, a site and medium of leisure in popular settings, was sharply criticised, and even fought against, in bourgeois and educational environments - a controversy that also reveals the anxieties brought on by the advent of modern industrial society (ibid.: 132-3; Schorb, 1995: 19-24). This led very quickly to measures enforcing state censorship and - particularly in Germany - campaigns to save children from the bad influence of the so-called Schundfilm (dirty movie) (Hüther, 2002b: 250). But there were also progressive educators in both countries who promoted a new educational paradigm, and who undertook to use film as an instructional tool. In France and in Germany, this new educational paradigm is called Nouvelle pédagogie or Reformpädagogik. Teachers began integrating film screenings in their teaching, and institutions were being established to produce and distribute films suitable for educational purposes (Landesbildstellen in Germany, the Pedagogical Museum - a precursor to CANOPE - in France) (Hüther, 2002c; Desbarats, 2002: 270-80). In Germany, the first community cinemas were created, which were supported by the state and offered an alternative programming to commercial cinemas, especially for the benefit of schools (Dierks, 2014). In France, secular activists, as well as the Catholic Church, 
organized after-school film screenings as a kind of 'educational leisure activity', and the reformist teacher Célestin Freinet experimented with lettres filmées, filmed letters exchanged between students of different regions (Desbarats, 2002: 278). Nonetheless, in this early period, film education in schools remained marginal, and was dominated by an instrumental approach, privileging documentary formats above all else.

As early as the 1920s, cultural initiatives and networks were also being developed within cinema culture that organized non-commercial screenings and established practices of mediation (screening events, debates, texts). In France, the (first) ciné-club movement took root mainly in bourgeois settings, among artists and intellectuals, and aimed to educate the public about cinema. Tied to avant-garde culture, the activities of the ciné-clubs were committed to creating a new audience and a new approach to the world by developing sensitivities towards film culture and aesthetics (Schlüpmann, 2004). In Germany, the avant-garde was similarly involved in the creation of ciné-clubs, setting its sights on aesthetic education. But in the politicised atmosphere of the Weimar Republic, politically motivated film societies emerged earlier, and were more important. With close ties to the Social Democratic Party and the Communist Party, the Volksfilmverband in particular was committed to providing a political education for the people - one that would counter the reactionary tendencies of the film industry and Weimar society - by showing and discussing films or clips of Soviet cinema, as well as films drawn from documentary, educational and avant-garde genres (Hagener, 2007: 85-90). Hence, differences in the respective strategies of mediation in France and Germany were already materializing very early at the heart of cinema culture. In Germany, film functioned primarily as a means of learning, whether as a form of political and moral education (in avant-garde and left-wing contexts) ${ }^{4}$ or as a didactic tool (in the context of the classroom). In France, within the framework of the ciné-clubs, film was regarded as an aesthetic object. According to this approach, the cultivation of taste would transform the individual's perception of the world. This cinephilia positioned itself against the didactic instrumentalization of cinema that dominated in school settings.

These two tendencies continue to characterize the development of film education up to the present day. In Germany, film's status as a mass media form is a matter of political education and politics - in a negative manner in the case of Nazi propaganda, and in a progressive manner in post-war ideological critiques. To this day, the main player in visual-media education is the Bundeszentrale für Politische Bildung (BPB, the national centre for political education). In France, on the other hand - with the second wave of the ciné-club movement - film was established as an aesthetic and cultural object, and the democratization of culture became a political priority of popular education.

\section{The institutionalization of film education by the state}

In Germany, cinema was already being instituted as a subject in schools during the 1930s. Upon coming to power, the National Socialists standardized the teaching of film in schools. They took up the concepts of Schulfilmbewegung, which was dedicated to promoting film as an instructional tool, and created in 1934 the Reichsanstalt für Film und Bild in Wissenschaft und Unterricht (RWU), a national producer of instructional films and teaching materials for film, with a decentralized distribution network of Landesbildstellen (visual media centres). Nearly all schools were equipped with $16 \mathrm{~mm}$ film projectors (Schorb, 1995: 26-8; Hickethier, 1974: 34-40). Film became an important medium of propaganda, with the film industry's totalitarian control and coordination (Gleichschaltung), but also with the 'cinema weeks' (Schulfilmwochen) that were 
organized in schools during the war, featuring mandated screenings of propaganda films. Propagandistic abuse went hand-in-hand with the destruction of any alternative film culture (which would largely be exiled to France, America and Russia). This impeded a more positive approach to film - and the post-war development of film education in West Germany for many years.

The democratic system of the Adenauer era, which took hold during the Cold War under the influence of the Allied forces, was dominated by the repression of the past and by institutional continuity, while the drive for renewal turned to materialism. The crisis of values initiated by the fall of the Nazi regime did not induce a confrontation with the past, but rather crystallized in moralistic campaigns against films with scandalous subject matter (Schorb, 1995: 30-42). There was continuity, with the production of Heimatfilm (homeland-film), a popular genre of 'escapist' cinema in the tradition of the UFA, as well as with the utilitarian approach to teaching cinema in schools promoted by the RWU, later known as the FWU (Institut für Film und Bild in Wissenschaft und Unterricht) - the national producer of instructional films today (Hickethier, 1974: 40-9). Moreover, this period saw a resurgence of the 'Bewahrpädagogik' approach, dating back to the beginning of the century, which promised to protect young people from the bad influence of contemporary films. This was achieved notably by introducing a system of age-based restrictions called Freiwillige Selbstkontrolle der Filmwirtschaft (FSK, a self-censorship initiative among production companies), a film-ratings system managed by the Filmbewertungsstelle Wiesbaden (FBW), and by efforts to foster an appreciation of 'good' films among young people in after-school ciné-clubs. ${ }^{5}$ Concepts of progressive education - developed by the pedagogue and resistance fighter Adolf Reichwein (who was killed by the Nazis), who worked during the 1930s with films to develop perception - were not taken up again. ${ }^{6}$ Instead, within the framework of education studies in universities, research was being conducted to study the influence of films on young people. Professors Martin Keilhacker and Fritz Stückrath became foundational figures for the future media pedagogy (Hüther, 2002a, 2002d). Most of these initiatives were distinguished by a desire to control and guide access to film - a medium that had proven dangerous. For the most part, they remained on the margins, as they lacked the support of a broader civic movement. In contrast, the state - where culture and education were once again strictly decentralized - continued to pursue the instrumentalist route that is still quite powerful today.

In France, the institutionalization of cinema in schools that took place in the 1980s was the result of a long democratic process tied to left-wing politics. The classroom, as an authoritarian institution, long remained rather hostile to the incorporation of visual media, most notably to cinema (Desbarats, 2002: 267-388). In the context of the Popular Front (a coalition of leftist parties who were in power between 1936 and 1938), the idea emerged of a politics for the democratization of culture, including cinema (de Baecque, 2008: 64-71). Here, too, the cinema becomes a political issue, but more pointedly in the sense of securing access to (elite) culture for all while, at the same time, validating popular culture. This idea gained momentum as part of the popular education movement after the Liberation, and would be taken up by the Mitterrand government that came to power in the 1980s. Cinema was institutionalized as an art and a cultural product by the Cannes Film Festival (founded by the Popular Front), the Cinémathèque française (established in 1936 as a private initiative and supported by the state since the Vichy regime), and the Centre national de la cinématographie (CNC, established 1946). ${ }^{7}$ Cinema would thus enter French classrooms in the 1980s as an art form. According to Francis Desbarats (2002: 267-388), two civic movements played a 
decisive role in the institutionalization of cinema in schools and in political discourse: the popular education movement after the liberation, and the May 1968 movement.

The post-war period saw a proliferation of initiatives and organizations in the realm of popular education that were dedicated to providing an education in democracy, by way of political and cultural education. They were subsidized by the state, the church and the political parties. In this context, the cinema, still the most popular medium of the time, and ciné-clubs, as sites of exchange between individuals belonging to different generations, social backgrounds and political affiliations, played an important role. This development occurred in tandem with a second cinephilia movement, led by ciné-club associations, and inspired by the variety of films - old and new, French and international - that were newly available after the period of wartime censorship, and that offered a vision of cinema as a historical horizon. Cultural practices that had already been developed in the first wave of cinephilia (programming, debates, criticism) moved beyond elitist circles and spread within the popular education movement, which continues to influence film culture and discourses around cinema in France to this day. While ideas about the secrecy of cinema experience and film as illegitimate object are fundamental to the myth of cinephilia, the approach of cinema as an art, including auteur theory and a comprehensive conception of cinema as cultural patrimony, helped legitimise film as an object of cultural value and erudition. Cinema is established as an object of, and a site for, education, mediation and transmission. On the one hand, in the discourse of cinephiles - especially in their autobiographical accounts - the cinema is described as a space in which to form one's gaze (apprentissage $d u$ regard), the best-known example being the New Wave directors who claimed the Cinémathèque française as their film school (Desbarats, 2002: 187-266; Henzler, 2013: 156-91). On the other hand, cinephiles were invested in popular education as a means of passing on their love of cinema: the most famous, André Bazin, combined his theoretical reflections on cinema with pedagogical engagement in popular ciné-clubs (both in France and abroad) (de Baecque, 2003: 33-62). However, although cinema had become an important issue in the debate around popular education, the EN remained reticent. It was individual cinephilic teachers, such as Henri Agel, who were instituting ciné-clubs in schools and writing the first film education textbooks. Their involvement was fuelled by a desire to transform the classroom by incorporating the mass media that fascinated younger generations, on the one hand, and, on the other hand, to teach cinema as an art form and a part of cultural heritage. This kind of cinephile education focused on the film viewer. Proposals by Célestin Freinet - a pioneer in the new education movement - for treating film as a communication medium and a practical experience, did not find a foothold (Desbarats, 2002: 338-42).

In Germany, too, there was a ciné-club movement after 1945, promoted by the Allies in the context of re-education, and influenced by French cinephilia. This movement played an important role in the re-establishment of a film culture after the war; it gave rise to festivals, community cinemas, film journals and new practices around the teaching of cinema. According to Anne Paech (1989), these ciné-clubs largely avoided political debates, and dedicated themselves instead to the discovery of (foreign) films of high aesthetic value. This, perhaps, was one of the reasons that the movement - after seeing great success in its first decade - ran out of steam in the late 1950s. The German ciné-club movement lacked the driving force of a more comprehensive civic movement, in a country where the majority wanted to forget, not confront the Nazi past or face the reality of the Cold War. It was not affiliated with the Friedensbewegung of the 1950s, which was committed to opposing rearmament and 
the inclusion of the FRG in NATO, and ended with the students' movement of the 1960s that finally broke the post-war silence, putting the past on the agenda.

Nonetheless, several important pioneering figures emerged from the German ciné-club movement: for example, Erika and Ulrich Gregor, the future founders of the Arsenal cinema and the Internationale Forum des Jungen Films in Berlin, fought to show neorealist and avant-garde films, and films from countries of the Far East, and to host political debates (Henzler and Zahn, 2014). And in the 1950s the Filmkritik newspaper, born of the post-war ciné-club movement, introduced an ideological critique in the tradition of Siegfried Kracauer in order to develop the political consciousness of the viewer with respect to contemporary large-scale productions, while remaining somewhat reserved on the subject of auteurist cinephilia (Frey, 2013).

\section{The role of civic movements}

The 1960s brought similar social and technological changes in both countries: the rebellion of the younger generations against authoritarian (and mercantilist) systems and values, and the establishment of ideological critique in the social sciences and the humanities, as well as the end of the ciné-club movement, with television replacing the cinema as the primary form of mass media. Semiotics and ideological critique in the structuralist tradition in France, and in the tradition of the Frankfurt School in Germany, contributed to changing perspectives on film: it was targeted as one of the forms of mass media whose ideological influence must be dissected and dismantled.

In Germany during the 1970s, the concept of Visuelle Kommunikation was developed in the context of arts education at university level. It called into question the existing canon and the bourgeois tradition of aesthetics in order to confront all the forms of visual communication in contemporary society (Hickethier, 1980: 217). Ideological critique in the Frankfurt School tradition attempted to analyse semiotic processes in the media, and to understand structures of production and reception as power systems (Schorb, 1995: 46-7). Very quickly, most notably with the broad distribution of video and VCR technology, these critiques were put into practice: everyone should have the possibility to seize the means of production in order to participate in collective communication actively, and to contribute to what Oskar Negt and Alexander Kluge (1972) called a Gegenöffentlichkeit (counter-public). The new German cinema was born from this wave, as well as diverse initiatives around praktische Medienarbeit, working with young people (and others) on practical media projects, in media centres or social work settings (Jugendsozialarbeit). ${ }^{9}$ At the same time, debates arose about the production of alternative films for children, which would give rise to children's film festivals, state-funded children's film production, and non-commercial distribution structures for children's films (Strobel, 1993). At a university level, film was being integrated into media studies (Medienwissenschaft), developed in the mould of literature and the humanities, ${ }^{10}$ and into the field of pedagogy, with the new subject of media education (Medienpädagogik). Drawing on Jürgen Habermas's concept of communication, professor of pedagogy Dieter Baacke developed a concept of handlungsorientierte Medienkompetenz - 'activity-oriented media competency' which would take hold in pedagogical discourses during the 1980s, and that remains powerful to this day. The concept is centred on the idea of emancipating the subject, which should be able to participate in social communication via the media.

In spite of these reform initiatives, film remained on the margins of the classroom - and this marginalization has continued to the present day. The development of new technologies leads, in cyclical waves, to the widespread furnishing of schools with the newest technologies, often without profound reflection on their pedagogical use 
and purpose. In the instrumentalist vein of education policy, the media are used as a medium of instruction (Mediendidaktik): language laboratories and educational television (Bildungfernsehen) during the 1960s and 1970s, computers in the 1980s, and ultimately digital media today (notably smart boards and tablets) (Schorb, 1995: 45-6 and 54). The earliest efforts of the assembly of the German state ministries of education (KMK) to incorporate media education into school curricula were thus focused on computer technology (Informationstechnologische Bildung). ${ }^{11}$ In 1995, the perspective was widened with a declaration by the KMK for the creation of media education programmes in schools, which would help students navigate the mediated world by way of informed choice, critique and creative practice. This was followed, in 2012, by the declaration mentioned above, and the latest nationwide strategy for 'Bildung in der digitalen Welt' (KMK, 2016), which looked to forge the digitization of all institutions of formal education, and the use of digital media as tool and subject of education.

Today, the inclusion of media in school curricula varies by state. Various subject areas (especially German and foreign languages, but also history and art) and various grade levels have become more open to teaching with, through, and about the media. Film is included in that category, and in some curricula it is mentioned explicitly. ${ }^{12}$ But which media to teach often remains the choice of individual teachers. In only a few states, such as Bremen, film appears as a topic in baccalaureate exams (as part of German, French or English language) (Middel, 2006; Vision Kino, 2018b).

The concept of Medienkompetenz still dominates in pedagogical and political discourses today, especially in relation to the competency-oriented trends in education following the PISA studies, and to current debates about the digitization of the public sphere, for example concerning privacy protection, cyber-bullying and manipulation (by so-called 'fake news'). Practical projects - implemented by media centres (before Landesbildstellen), public-access channels (Offene Kanäle), LISUM (a regional teacher training centre), and film festivals (such as Goldener Spatz in Gera and Erfurt, or Internationale Kinderfilmfestival Lucas in Frankfurt) - and diverse pedagogical concepts have proliferated. But despite its initial emancipatory aims, the concept has also been emptied of meaning during its dissemination, and has proved susceptible to being instrumentalized by political discourses, which constantly oscillate between technocratic enthusiasm and the debates around violence and misuse that loom with each new form of media that arrives: the instrumental approach and the critical approach remain the most powerful in the realm of German education politics.

In 1970s France, too, semiotics and ideological criticism became the dominant discourses around cinema and the image, influencing theoretical work in universities as well as film criticism. Semiotics played the role of cinephilia's 'exorcist' (exorcising its aberrations). It helped establish film as an object of scientific study, and furnished methods (especially those put forward by Christian Metz and Roland Barthes) for analysing films in the classroom. Within the framework of the movement of '68, a second wave of progressive initiatives was born that sought to reform the school (as an authoritarian structure) by incorporating media drawn from the daily lives of young people. Debates were flaring up around the canon of literary education, and pilot programmes in film education were launched - which would combine analysis and practice, cinephilia and semiotics (Desbarats, 2002: 343-81). But although the semiological approach resembled media pedagogy methods in Germany, attending to all forms of media and favouring ideological critique, there were also different tendencies at play. Anchored in the French structuralist tradition, semiological approaches were nonetheless more open to cultural history, and more open to film 
as an object of study. Above all, however, by focusing on analysis (whether systematic or textual) with the intention of training critical 'readers', these approaches tended to ignore film production as well as the subject of the student. ${ }^{13}$ They would have a great influence - most notably on the teaching of cinema in humanities departments and discourses - but would not replace the cinephiliac practices and approaches in the long term. As Francis Desbarats has demonstrated, cinephilia, semiotics and the visual arts - incorporating artistic practice - would play a decisive role in the establishment of cinema education in schools.

Starting in the 1980s, cinema began to be institutionalized as educational subject matter in France over several stages. The leftist government, in a collaboration between the ministries of culture and education, launched policies that promoted arts education in schools, following the tradition of popular education. Thus it was by way of the arts, and with the support of cultural institutions, that cinema entered the classroom. Among other things, a baccalaureate exam in 'cinema and audiovisual media' was created within the framework of electives and required courses in high schools specializing in these topics (lycée), and cinema was introduced into literature curricula in high schools more generally (featuring on assessment exams since the 1990s). In order to introduce cinema education to all schools and age groups, various nationwide programmes were implemented after 1989: Collège au cinéma (for middle schools) and Lycéens et apprentis au cinéma (for high-school and trade students) were both initiated by the CNC (National Film Funding). École et cinéma for primary education was established by the independent association Les enfants de cinéma, which in later years also developed an educational programme for nursery schools. And Un été au ciné (now known as Passeur d'images) run by Kyrnéa International, organizes extra-curricular film projections in underprivileged communities. ${ }^{14}$ This institutionalization of film education in schools inspired a wealth of new textbooks (including the journal Cahiers des ailes du désir (ailesdudesir.fr)), video essays and pedagogical material about the films shown in the programmes - often written by film critics and other prominent cinephiles. These programmes and publications developed methods of mediating cinema as an aesthetic experience and a cultural heritage. Contemporary films are taught alongside works from film history.

Between 2000 and 2002, Minister of Education Jack Lang (formerly the Minister of Culture) launched an ambitious project in cooperation with Catherine Tasca, who was Minister of Culture at the time. Les arts à l'école (The Arts in the Classroom) placed arts education for all, from the first class levels, at the centre of the education system. The programme toughened up the existing strategies of cultural democratization: alongside the development of taste through access to artworks, artistic practice would be standardized in the form of artistic projects called Classes à projet artistique (PAC). These PAC classes reached students of all ages, and were organized as collaborations between teachers and artists. With these initiatives, Lang and Tasca were returning to the idea of personal development by way of aesthetic education, as a 'counterweight' against the dominant influence of media industries, and as a strategy to foster the equality of opportunity - having been called into question by Pierre Bourdieu's sociological studies (Lismonde, 2002; Montoya, 2009). ${ }^{15}$ For cinema, this implied a combination between the project of cinephilia (the development of perception and the formation of the gaze through a confrontation with aesthetic works), the project of popular education (access to art for all) and the project of the new education movement (artistic practice). Alain Bergala, former Cahiers du cinéma critic and professor of cinema at various universities and the Paris film school (Fémis), took responsibility for the cinema arm of Lang's project. In addition to the promotion of artistic film projects (PAC), 
Bergala published a series of DVDs for classroom use (Eden cinéma), which offered new methods for film education. In his treatise L'Hypothèse cinéma, first published in 2002 (The Cinema Hypothesis, English translation, 2016), he describes his approach to cinema as an art form, derived from the cinephilia tradition, and renews it - combining analysis with practice, and integrating hypertextual methods developed for the DVD. The book draws on his long-standing commitment to visual-media education, which dates back to the 1970s. The most remarkable outcome of this engagement is the project 'Le cinéma, cent ans de jeunesse', which he founded together with Nathalie Bourgeois in 1995 at the Cinémathèque française, and which has continued to develop on an international scale, with around forty participating classes across more than ten countries in Europe and overseas today (La Cinémathèque française, 2013).

The programme that Lang and Tasca envisioned was not fully realized, as subsequent administrations have reduced its scope by degrees. Eden cinéma was discontinued in 2012, following the production of 30 DVDs of exceptional richness and quality. But the programme has retained its influence into the present day, both in practice - since PAC classes, though reduced in number, are still financed - and symbolically, with the international reception of L'Hypothèse cinéma, translated into several foreign languages. Les arts à l'école programme has revived the discourse of cinephilia in the fields of cultural mediation and cinema education, where it remains full of vigour (Montoya, 2009; Boutin, 2010).

\section{Concepts: Teaching cinema as art or developing media literacy?}

Having recounted the historical development of two kinds of discourse around film education, I would like briefly to discuss certain inherent modes of reasoning that contribute - in my opinion - to the creation of 'facts'. For this purpose, I will use the examples of two key concepts: Alain Bergala's concept of film education, inscribed in 2002's The Cinema Hypothesis, and Dieter Baacke's work on Medienkompetenz, revisited in a 2003 essay collection about the current status of Medienkompetenz in Germany (Bergala, 2002; Bergmann et al., 2004). ${ }^{16}$ Although these examples are different in character, they can function as representative cases with which to outline different strategies that share a common fundamental objective: to emancipate young people in the face of a very powerful industrial media culture.

The central notion of Dieter Baacke's pedagogical theory is Medienkompetenz, which is based on Jürgen Habermas's sociological concept of communicative action, and Noam Chomsky's linguistic concept of competence (Baacke, 2004; cf. Schorb, 1995: 48-50). According to Baacke, participation in the process of social communication is a question of social and individual emancipation. From this perspective, then, media education should develop competencies in communicating with media, and in navigating and acting within a media-saturated world (Handlungskompetenz). The concept of Medienkompetenz that Baacke proposes implicitly incorporates three trends that shaped film education in Germany (and that we continue to see in the KMK report cited above): (1) media critique, understood as the ability to understand, evaluate and choose - which took the place of the sceptical tradition of Bewahrpädagogik; (2) the use of media as a didactic tool and the acquisition of technological proficiency - the instrumentalist approach; and (3) a new approach: creative practice (Mediengestaltung) as a contribution to social communication. ${ }^{17}$

Baacke's conception of Medienkompetenz involves aspects of information technology, entertainment and aesthetic education (Baacke, 1997: 24). But the logic 
of the discourse actually yields some exclusions, which are demonstrated in the text cited. First, the notion of 'media' does not distinguish between forms as different as newspaper, radio, television, cinema, the internet (e-shopping) and computers, and thus tends to impede the development of specific disciplines. ${ }^{18}$ This tendency is reinforced by the focus on the subject of communication, which discourages paying attention to the role of concrete objects (especially aesthetic objects) in the learning process. However, while in principle this discourse does not define specific objects and media forms, its implicit primary focus is on current social media practices and is thus closely aligned with the daily lives of the younger generations. ${ }^{19}$ This tendency can also be found in more recent pedagogical discourses that assert a distinction between object-oriented and subject-oriented film pedagogies - a binary argument through which the proponents question the cinephile initiatives that have emerged in recent years (following the publication of The Cinema Hypothesis in Germany in 2006) (Niesyto, 2006: 8). ${ }^{20}$ But this opposition seems problematic, even false, if we regard aesthetic experience as an interrelation between subject and object, where one depends on the other - as aesthetic and phenomenological theories describe it (Henzler, 2010). Moreover, the notion of competence, though considered by Baacke to be an innate quality that develops over the course of one's life, often implies a pedagogical concept of mastery, and is directed at a subject who is/becomes an autonomous actor. This ignores the formative and educational value of irritation, of losing one's bearings and confronting alterity, ${ }^{21}$ and also contradicts a non-functional conception of Bildung as subject formation. These contradictions are apparent in a more recent pedagogical debate around the notions of Medienkompetenz and Medienbildung (see, for example, Schorb, 2009; Spanhel, 2010). What is more, when Baacke anchors Medienkompetenz in a basic concept of communication and action through communication, he implicitly assumes that the relation between the subject and the world is the only effect of communication. Thus his vision of education is aimed at the discourses of society in the present moment - neglecting the dimension of cultural history in which every subject is inscribed, as well as the sensorial aspects of reception. Thus, in the publication containing Baacke's text, there are also two articles that critique precisely the absence of aesthetics in the concept of Medienkompetenz. ${ }^{22}$

It should be emphasized, of course, that this outline is incomplete in its account of the variety of visual-media education practices in Germany, and of the recent development of different concepts in media pedagogy, which also grapple with questions of emotion, aesthetics and fantasy. (See the articles by Lothar Mikos and Norbert Neuß in Bergmann et al., 2004). But it identifies within the discourse a logical framework, related to the notion of competence, which has had the greatest influence on the political discourse, probably because it offers an agreeable context for each new technology that emerges. At the same time, this discourse obstructs the development of cinema education, and thus the positioning of cinema in discourses about art. Regarding film, it should be added that Medienpädagogik, as a category of pedagogy, is clearly distinct from the development of teaching practices that use film in other subject areas (notably literature, foreign languages and art), but it is also detached from film studies research and teaching in universities. As for Medienwissenschaft, having long neglected questions of pedagogy, the Gesellschaft für Medienwissenschaft has begun in recent years to contribute to political debates around standardizing Medienbildung as a form of cultural education that also includes the historical and aesthetic dimensions of media. ${ }^{23}$

In The Cinema Hypothesis, Alain Bergala proposes a pedagogy of film-as-art. He integrates the cinephile approach (teaching cultural heritage and film appreciation) with 
artistic practice and the digital as an intertextual methodology. With his pedagogical concept, he positions himself against the rationalist tendencies of the classroom, which he perceives to be supported by the methods of semiotics and ideological critique. His argument functions, according to binary oppositions, between cinema-as-art and mass media, alterity ${ }^{24}$ and ideology, creativity and mastery. The discourse of cinephilia, within which Bergala is placed, operates conversely to the discourse of Medienkompetenz: it foregrounds aesthetics as distinct from communication. This approach can be critiqued as a strategy for legitimising cinema as an art form - not unlike auteur theory (Pauleit, 2009)..25 But I propose instead that the difference that Bergala emphasizes should be interpreted as an indication of two different levels of reception: a functional level (described in sociological and communications theory) and an aesthetic level (defined by aesthetic theories dating back to Kant, and that can also be found, for example, in Barthes's distinction between the obvious and the obtuse). ${ }^{26}$ From this perspective, the concept suggested by Bergala (and Lang) would offer the privilege of aesthetic education to all students. And thus it would revive the ideal of democratization and the development of the individual through culture - but based on the sociological theory of taste formation. When Bergala - and the discourse of cinephilia - draws a line of distinction between art and mass communication, inarguably problematic from a systematic point of view, he is simultaneously identifying the innate contradictions of the medium of cinema, which participates in the institution of art as well as the industry of mass communications. Likewise, he emphasizes elements that, in the discourse around communications (which attempts to refer to the media as a comprehensive whole), are often implicitly denied. Thus, this approach turns out to be more global in scope with regard to the educational potential of cinema, comprising cinema in its variety of aesthetics, genres and ages, and also its pedagogical implications, as it reflects the importance of a sensuous perception of the world, of the broadening of one's mind by the encounter with alterity, as well as of the intertextual relation of images, for formative processes. Bergala's idea of aesthetic education (whether by way of reception or production) is rooted in the conviction that a subject is formed in a confrontation with concrete objects, that there is an individual dimension to learning that 'resists' social forms, and that in the process of teaching cinema at least three 'subjects' are in play: the child, the teacher and the film. ${ }^{27}$

\section{Conclusion}

With this description of the parallel developments of concepts in Medienkompetenz and arts education, I have tried to sketch an outline of the dominant discourses around film education in France and Germany that have in turn influenced the political discourses mentioned above. This outline is, of course, not comprehensive in its account of the variety of approaches in both countries. Especially in Germany, the situation has changed since 2000, when, at the national level, several projects and initiatives emerged for teaching cinema culture, outside the field of media pedagogy - borne by state institutions (the bpb; the BKM/Ministère de la culture; the French Embassy) and film professional associations (FFA, the German CNC; AG Kino-Gilde e.V., the Association of Arthouse Cinemas). Nationwide projects such as Cinéfête (launched in 2000 by the French Embassy) and Schulfilmwochen (today known as Schulkinwochen, started in 2002 by the Institut für Kino und Filmkultur e.V.) were born, organizing cinema weeks for schools in various regions and cities. ${ }^{28}$ Vision Kino, a national network for cinema education, was created by the Ministère de la culture, the FFA, and professional associations. In this vein, the bpb begun to publish pedagogical 
material on films, launched a 'canon' of classic films to see in school and, most recently, initiated, together with the German Film Academy, the educational project for film classics Klassiker Sehen, Filme Verstehen (Holighaus, 2005). Other projects developed new approaches to film education, such as the children's documentary film festival in Duisburg, the Minifilmclub of experimental cinema for children in kindergarten by the Frankfurt Film Museum and the Living Archive of Arsenal - Institut für Kino und Filmkultur in Berlin. Instructional publications on film are proliferating, especially in connection with literary studies, and various training schemes for teachers at regional and local levels exist. Universities, such as Bremen, Freiburg or Hildesheim, have established the field of cinema education (Filmvermittlung) within the frameworks of arts education, interdisciplinary teacher training and film studies - combining analysis and practice, and incorporating the practices of institutions and cultural actors. The aesthetic approach has become increasingly important in film education, a fact that also demonstrates the success of the publication of The Cinema Hypothesis in German (Bergala, 2006).

In spite of all these initiatives, however, aesthetic approaches remain marginal, and there is still a lack of systematic integration of film education across all states and age groups. This is especially true as the guidelines recommending Medienbildung in the curricula of different subject areas cannot guarantee that a given teacher will teach film, or that he or she will be trained to teach it, or that film will be included as a subject of testing, which would give it greater weight in education policy. Political discourses are dominated by the idea of media competency, and the latter has very quickly shifted its priorities in the direction of new media, with the new national strategy of 'education in the digital age'. Even cultural initiatives that support cinema education are influenced by the power of cultural discourses and traditions. For example, the choice of films is focused mostly on recent releases (and fictional narratives), and classic films appear only in specific programmes, mostly designed for high schools. This demonstrates the status of film as a 'contemporary' medium, and contrasts with approaches that regard cinema as a historical ensemble, which, for example, characterizes the children's programme École et cinéma in France. Similarly, the selection of films in German projects and programmes is often legitimated by the content, and less by the aesthetic quality, of a film: what matters are the themes covered in school curricula, subjects of political and historical instruction, and the current lived reality of young people. In pedagogical material published for the films in the programmes, one often finds a distinction between the descriptions of content and of political, cultural and historic context, on the one hand, and of formal analysis (of sequence, strategy and aesthetics) on the other hand. ${ }^{29}$ In French pedagogical material, in contrast, the aesthetic is analysed as a means of understanding the whole, the content, the historical context, but also of the director as an author..$^{30}$ Pedagogical material from Germany is often more didactic, proposing educational activities, questions and exercises, such as gapfill word games, role-plays, art projects (for children) or even film production analyses (for example, a comparison between the screenplay and the image). This perhaps addresses the apprehensions of teachers, who feel themselves to be at a loss when faced with the complexity of a film, but it also shows parallels to a media pedagogy that aims at an active subject, an 'actor'.

The cinephile's approach to cinema can be critiqued for certain ideological implications of the disjunction between cinema-as-art and mass media in the discourse of cinephiles, and the idealization of the revelatory encounter with the artwork in discourses around the mediation of art. ${ }^{31}$ But I hope to have shown with this article that media pedagogies in Germany also imply ideological contradictions - even if they 
seek to account for all media forms, in a way that is pragmatic and oriented towards the lived reality of young people and media industries (just as with other concepts of media literacy around Europe). The focus on media - without distinguishing between different forms of expression - goes hand-in-hand with a communications-based approach, and easily leads one to ignore the aesthetic and historical aspects of cinema, and to dismiss the value of aesthetic experience as a matter of initiation and access to the world. It is therefore a matter of two different paradigms that approach cinema in its ambiguous status, caught between industry and art, which were developed in different historical and theoretical contexts. We should not think of them as ontologies, but rather as different pedagogical strategies - which implicitly construct their object, as well as the child-subject. From this perspective, the media-pedagogy approach has impeded the development of film education in Germany, while the cinephile approach has proven to be more productive, giving rise to a multiplicity of practices, methods and approaches with a remarkably high degree of rigour and quality.

\section{Notes}

1. According to Große, the transitive concept of education (to educate someone) bears traces of the Jesuit school tradition, and is more focused on the individual's integration in a culture and a society, while the intransitive concept of Bildung (sich bilden, meaning to form oneself, or roughly to cultivate oneself) is rooted in the traditions of Humboldt and Protestantism, and centres on the training of the individual in an exchange with the world (Große, 2008: 241-3).

2. 'Dès l'école primaire, l'éducation à l'image, au cinéma et à l'audiovisuel permet aux élèves d'acquérir une culture, d'avoir une pratique artistique et de découvrir de nouveaux métiers' (Ministère de l'Éducation nationale, 2017).

3. '[Schulische Medienbildung] zielt auf Erwerb und die fortlaufende Erweiterung von Medienkompetenz, also jener Kenntnisse, Fähigkeiten und Fertigkeiten, die ein sachgerechtes, selbstbestimmtes, kreatives und sozial verantwortliches Handeln in der medial geprägten Lebenswelt ermöglichen' (KMK, 2012: 3).

4. Heide Schlüpmann shows that this holds true in the criticism and film theory of Siegfried Kracauer and Béla Balász (Schlüpmann, 2004: 30-1).

5. The first textbooks on visual-media education also appeared in the same context (Hickethier, 1974).

6. Adolf Reichwein worked with documentary film. His most important book, Film in der Schule: Vom Schauen und Gestalten, was not reprinted until 1967 (Reichwein, 1967).

7. In Germany, the national film archive was founded in the 1930s, but the majority of film institutions, including cinematheques and community cinemas, would be founded in the 1960s and 1970s - that is, after the first wave of institutionalization in which Nazi policies brought cinema into schools.

8. Per Paech, the ciné-club movement was initially very successful (with 150,000 members by the mid-1950s). The first meetings of the association of ciné-clubs were organized under French supervision, supported by French intellectuals and artists including, among others, André Bazin and Chris Marker (Paech, 1989).

9. Media practice was happening in classrooms only at the initiative of individual educators in the arts, literature and social sciences. But there were also opportunities to work with young people outside school hours (Jugendarbeit). Alternative media centres were established, including, for example, Medienpädagogik Zentrum Hamburg (1973) and Medienoperative Berlin (1977) (Paech, 1974).

10. It should be emphasized that Medienwissenschaft in Germany, administered by the Gesellschaft für Medienwissenschaft (GFM) society, was an offshoot of the humanities, and distinguished itself from the field of communication sciences governed by the Deutsche Gesellschaft für Publizistik und Kommunikationswissenschaft (DGPuK) society, which was derived from the field of journalism studies. Media pedagogy, in contrast, was more closely associated with communications theory.

11. See 'Gesamtkonzept für die informationstechnische Bildung' by the Bund-Länder-Kommission, 1987, describing the initiatives of the various German states, and proposing new ideas for their development (BLK, 1987).

12. In the states of Bremen, Baden-Württemberg and Niedersachsen, film is named in curricula of German literature. In Berlin-Brandenburg, a specific film curriculum was introduced in 2016, which proposes film education across all subjects from the first to the tenth level (see Vision Kino, 2018b). 
13. See the detailed analysis of semiotics textbooks published for humanities departments by Francis Desbarats (2002: 461-507), which demonstrates the technical tendency at work, and Alain Bergala's critique in his book Pour une pédagogie de l'audio-visuel, where he proposes an approach that integrates analysis and practice (Bergala, 1975).

14. Today these programmes reach close to 1.4 million young people each year (CNC, n.d.).

15. The politics of cultural democratization were called into question by the sociological studies on Les pratiques culturelles françaises conducted by the Minister of Culture, which showed that the cultural habits of the French were differentiated according to social class (with the trend holding in 1973, 1981, 1989 and 1997). Lang's idea could be interpreted as a reaction to this critique (Henzler, 2013: 78-119).

16. The article summarizes the approach that Baacke had been developing since the 1970s, and which he described more fully in his book, Medienpädagogik (Baacke, 1997). The essay collection (called a 'handbook') was published by Bundeszentrale für politische Bildung, and was recently replaced by a new version, which focuses more closely on digitization. This new version seems to enforce the analysed tendency to ignore film and aesthetic education, mostly focusing on processes of communication and the public space. Film is rarely named, mostly in historical overviews, and only one article briefly mentions the possibility of a creative approach to animation films as a means to 'educate' Medienkompetenz. Nevertheless, I will analyse the older version, as it was published around the same time as The Cinema Hypothesis, and as it focuses on the pedagogical concept that introduced the notion of Medienkompetenz in Germany (Gapski et al., 2017).

17. Cf. the components named by Dieter Baacke: (1) Medienkritik; (2) Medienkunde; (3) Mediennutzung; (4) Mediengestaltung (Baacke, 1997: 24).

18. Cf. the critique of the concept of Medienkompetenz by Norbert Neuß in the same publication (Neuß, 2004).

19. Baacke also refers to the 'computerized' world (Baacke, 1997: 21).

20. According to Schädler (2008: 21-39), a distinction is often made between 'authentic' images, particular to young people and created in the course of hands-on practice, and 'media products', the objects of ideological critique.

21. For a critique of the functionality of contemporary concepts in film education and the strategy of confronting alterity in educational settings, see Zahn (2012: 18-27).

22. If we consider the diversity of the 93 projects presented in the same publication, we find projects in ecological education, play-oriented teaching devices, media art, and studies of genre and media, with the majority of projects focused on practical skills, including 20 involving computers and the internet, 13 involving news broadcasts, 8 working with video, 7 engaging with films, and a project on cinematic patrimony (Bergmann et al., 2004).

23. The GFM notably established a working group, AG Medienkultur und Bildung, and published position papers that demanded the inclusion of media science in the development of media education and commented on the national strategies on media education (GfM, 2018).

24. I prefer this literal translation of the word alterité used by Bergala, for its broader theoretical implications, instead of 'otherness', used in the English translation of the text.

25. On cultural legitimization in the discourse of cinephilia, see Jullier and Leveratto (2010).

26. Ulrich Richtmeyer proposes these two levels of reception as a way to integrate Barthes's and Bourdieu's theories of photography. He relates these to the aesthetic theory of Immanuel Kant (Richtmeyer, 2009).

27. Regarding the theoretical foundations of the approach that Alain Bergala proposes, see Henzler (2013).

28. This programme, intended for all ages, today reaches about 900,000 students each year (Vision Kino, 2018c).

29. See, for example, the projects and pedagogical material of the two national institutions for film education, the Bundeszentrale für politische Bildung (BPB, n.d.) and Vision Kino (Vision Kino, 2018a).

30. See, for example, the pedagogical material from the national programmes École et cinéma, Collège au cinéma, Lycéens et apprentis au cinéma (Les enfants de cinéma, 2018; CNC, n.d.).

31. See Jullier and Leveratto (2010: 35- 7) regarding the cinephile discourse about cinema-as-art eclipsing the viewer's pop culture knowledge. For more on the 'encounter' in discourses on mediation, see Montoya (2009: 325).

\section{Notes on the contributor}

Bettina Henzler is a research associate and lecturer at the University of Bremen and is currently overseeing the DFG-funded research project Filmästhetik und Kindheit (Film 
Aesthetics and Childhood; www.film-und-kindheit.de). She wrote her PhD thesis on the theoretical and historical contexts and practical implications of Alain Bergala's proposal of an aesthetic film education in France (Filmästhetik und Vermittlung, Marburg 2013). Since 2002 she has directed the national French School Film Festival, Cinéfête, and works as a freelance film education consultant in cooperation with international film institutions. She has co-edited, among others, Learning from the Cinema (Bertz and Fischer, 2010) and Childhood, Cinema and Film Aesthetics (Bertz and Fischer, 2018).

\section{References}

Baacke, D. (1997) Medienpädagogik (Grundlagen der Medienkommunikation 1). Tübingen: Niemeyer.

Baacke, D. (2004) 'Medienkompetenz als zentrales Operationsfeld von Projekten'. In Bergmann, S., Lauffer, J., Mikos, L., Thiele, G.A. and Wiedemann, D. (eds) Medienkompetenz: Modelle und Projekte. Bonn: Bundeszentrale für Politische Bildung, 21-5.

Bergala, A. (1975) Pour une pédagogie de l'audio-visuel. Paris: Ligue française de l'enseignement. Bergala, A. (2002) L'hypothèse cinéma: Petit traité de transmission du cinéma à l'école et ailleurs. Paris: Cahiers du cinéma.

Bergala, A. (2006) Kino als Kunst: Filmvermittlung an der Schule und anderswo. Ed. Henzler, B. and Pauleit, W. Trans. Heber-Schärer, B. Marburg: Schüren.

Bergala, A. (2016) The Cinema Hypothesis: Teaching cinema in the classroom and beyond (FilmmuseumSynemaPublikationen 28). Trans. Whittle, M. Vienna: Austrian Film Museum.

Bergmann, S., Lauffer, J., Mikos, L., Thiele, G.A. and Wiedemann, D. (eds) (2004) Medienkompetenz: Modelle und Projekte. Bonn: Bundeszentrale für Politische Bildung.

BLK (Bund-Länder-Kommission für Bildungsplanung und Forschungsförderung) (1987) Gesamtkonzept für die informationstechnische Bildung (Materialien zur Bildungsplanung 16). Bonn: Bund-Länder-Kommission für Bildungsplanung und Forschungsförderung. Online. www.blk-bonn.de/papers/heft16.pdf (accessed 13 March 2018).

Boutin, P. (2010) 'Le 7e art aux regards de l'enfance: Les méditations dans les dispositifs d'éducation à l'image cinématographique'. Unpublished doctoral thesis, Université d'Avignon.

BPB (Bundeszentrale für politische Bildung) (n.d.) 'Filmhefte'. Online. www.bpb.de/shop/lernen/ filmhefte/ (accessed 24 January 2018).

CNC (Centre national du cinéma et de l'image animée) (n.d.) 'L' éducation à l'image'. Online. www.cnc.fr/web/fr/education-a-l-image (accessed 24 January 2018).

de Baecque, A. (2003) La cinéphilie: Invention d'un regard, histoire d'une culture, 1944-1968. Paris: Fayard.

de Baecque, A. (2008) Crises dans la culture française: Anatomie d'un échec. Paris: Bayard.

Desbarats, F. (2002) 'Origines, conditions et perspectives idéologiques de l'enseignement du cinéma dans les lycées'. Unpublished doctoral thesis, Université de Toulouse-Le Mirail.

Dierks, K. (2014) 'Der Kampf um die Bilder: Anmerkungen zu frühen Formen kommunaler Filmarbeit'. In Pauleit, W., Rüffert, C., Schmid, K.-H., Tews, A. and Odorico, S. (eds) Filmerfahrung und Zuschauer: Zwischen Kino, Museum und sozialen Netzwerken. Berlin: Bertz + Fischer, 20-7.

Frey, M. (2013) 'Filmkritik, with and without italics: Kracauerism and its limits in postwar German film criticism'. New German Critique, 40 (3), 85-110.

Gapski, H., Oberle M. and Staufer W. (eds) (2017) Medienkompetenz: Herausforderungen für Politik, politische Bildung und Medienbildung. Bonn: Bundeszentrale für politische Bildung.

GfM (Gesellschaft für Medienwissenschaft) (2018) 'AG Medienkultur und Bildung'. Online. www.gfmedienwissenschaft.de/ag-medienkultur-und-bildung (accessed 24 January 2018).

Große, E.U. (2008) 'Das Bildungswesen: Tradition und Innovation'. In Große, E.U. and Lüger, H.-H. (eds) Frankreich verstehen: Eine Einführung mit Vergleichen zu Deutschland. 6th ed. Darmstadt: Primus, 198-243.

Hagener, M. (2007) Moving Forward, Looking Back: The European avant-garde and the invention of film culture, 1919-1939. Amsterdam: Amsterdam University Press.

Henzler, B. (2010) 'Me you he she it: Intersubjectivity in film education and mediation'. In Henzler, B., Pauleit, W., Rüffert, C., Schmid, K.-H. and Tews, A. (eds) Learning from the Cinema: International perspectives on film education. Berlin: Bertz + Fischer, 73-89.

Henzler, B. (2013) Filmästhetik und Vermittlung: Zum Ansatz von Alain Bergala: Kontexte, Theorie und Praxis (Bremer Schriften zur Filmvermittlung 3). Marburg: Schüren. 
Henzler, B. (2015) '“Éducation à l'image" et "Medienkompetenz": Quelques différences dans I'enseignement du cinéma à l'école, en France et en Allemagne'. Mise au point, 7. Online. http://journals.openedition.org/map/1876 (accessed 22 February 2018).

Henzler, B. and Zahn, M. (2014) '“Wir setzen einfach darauf, dass die Begeisterung für Film und Kino immer weitergeht": Notizen zu einem Gespräch mit Erika und Ulrich Gregor'. Filmvermittlung, 13. Online. http://geschichte.nachdemfilm.de/content/wir-setzen-einfach-darauf-dass-diebegeisterung-f\%C3\%BCr-film-und-kino-immer-weitergeht (accessed 13 March 2018).

Hickethier, K. (1974) ,Zur Tradition schulischer Beschäftigung mit Massenmedien: Ein Abriß der Geschichte deutscher Medienpädagogik'. In Schwarz, R. (ed.) Manipulation durch Massenmedien - Aufklärung durch Schule? Eine Bestandsaufnahme (Didaktik der Massenkommunikation 1). Stuttgart: Metzler, 21-52

Hickethier, K. (1980) ,Methoden und Probleme einer Geschichte der Medienpädagogik nach 1945'. Medien und Erziehung, 24 (4), 212-18.

Holighaus, A. (ed.) (2005) Der Filmkanon: 35 Filme, die Sie kennen müssen. Berlin: Bertz + Fischer.

Hüther, J. (2002a) ,Wegbereiter der Medienpädagogik (4): Martin Keilhacker (1894-1989)'. Medien und Erziehung, 46 (2), 118-21.

Hüther, J. (2002b) 'Wegbereiter der Medienpädagogik (6): Die Kinoreformer, 1907-1920'. Medien und Erziehung, 46 (4), 248-51.

Hüther, J. (2002c) 'Wegbereiter der Medienpädagogik (7): Die Schulfilmer'. Medien und Erziehung، 46 (5), 320-3.

Hüther, J. (2002d) 'Wegbereiter der Medienpädagogik (8): Fritz Stückrath (1902-1974)'. Medien und Erziehung, 46 (6), 391-4.

Jullier, L. and Leveratto, J.-M. (2010) Cinéphiles et Cinéphilies: Une histoire de la qualité cinématographique. Paris: Armand Colin.

KMK (Kultusministerkonferenz) (2012) Medienbildung in der Schule (Beschluss der Kultusministerkonferenz vom 8. März 2012). Berlin: Kultusministerkonferenz. Online. www.kmk. org/fileadmin/Dateien/veroeffentlichungen_beschluesse/2012/2012_03_08_Medienbildung.pdf (accessed 13 March 2018).

KMK (Kultusministerkonferenz) (2013) Empfehlung der Kultusministerkonferenz zur kulturellen Kinder- und Jugendbildung (Beschluss der Kultusministerkonferenz vom 01.02.2007 i. d. F. vom 10.10.2013). Berlin: Kultusministerkonferenz. Online. www.kmk.org/fileadmin/Dateien/pdf/ Themen/Kultur/2007_02_01-Empfehlung-Kulturelle_Bildung.pdf (accessed 24 January 2018).

KMK (Kultusministerkonferenz) (2016) Bildung in der digitalen Welt: Strategie der Kultusministerkonferenz. Berlin: Kultusministerkonferenz. Online. www.kmk.org/fileadmin/ Dateien/pdf/PresseUndAktuelles/2018/Digitalstrategie_2017_mit_Weiterbildung.pdf (accessed 13 March 2018).

La Cinémathèque française (2013) 'A propos du Cinéma, cent ans de jeunesse'. Online. http:// blog.cinematheque.fr/100ans20132014/a-propos-du-cinema-cent-ans-de-jeunesse (accessed 20 November 2014).

Les enfants de cinéma (2018) 'Les enfants de cinéma: Susciter un désir de cinéma'. Online. http:// enfants-de-cinema.com/ (accessed 24 January 2018).

Lismonde, P. (2002) Les arts à l'école: Le plan de Jack Lang et Catherine Tasca. Paris: Gallimard.

Middel, R. (2006) Film in Rahmen-/Lehrplänen einzelner Bundesländer. Berlin: Vision Kino. Online. www.visionkino.de/fileadmin/user_upload/kongress/2006/0.3_Film_Lehrplaene_Middel.pdf (accessed 13 March 2018).

Ministère de l'Éducation nationale (2014) 'Éducation et médias: Un nouveau site pour découvrir, comprendre et décrypter les médias audiovisuels et leurs pratiques'. News brief, 15 January. Online. www.education.gouv.fr/cid76132/education-medias-un-nouveau-site-pour-decouvrircomprendre-et-decrypter-les-medias-audiovisuels-et-leurs-pratiques.html (accessed 24 January 2018).

Ministère de l'Éducation nationale (2017) 'L'éducation à l'image, au cinéma et à l'audiovisuel'. Online. www.education.gouv.fr/cid21004/l-education-a-l-image-au-cinema-et-a-l-audiovisuel. html (accessed 24 January 2018).

Ministère de l'Éducation nationale (2018) 'L'éducation artistique et culturelle'. Online. www. education.gouv.fr/cid20725/l-education-artistique-et-culturelle.html (accessed 24 January 2018).

Montoya, N. (2009) 'Médiateurs et dispositifs de médiation culturelle: Contribution à l'établissement d'une grammaire d'action de la démocratisation de la culture'. Unpublished doctoral thesis, Université de la Sorbonne nouvelle - Paris III.

Negt, O. and Kluge, A. (1972) Öffentlichkeit und Erfahrung: Zur Organisationsanalyse von bürgerlicher und proletarischer Öffentlichkeit. Frankfurt am Main: Suhrkamp. 
Neuß, N. (2004) 'Medienpädagogische Projekte - wozu? Problemlagen - Utopiebereitschaft Erinnerungsarbeit'. In Bergmann, S., Lauffer, J., Mikos, L., Thiele, G.A. and Wiedemann, D. (eds) Medienkompetenz: Modelle und Projekte. Bonn: Bundeszentrale für Politische Bildung, 32-9.

Niesyto, H. (ed.) (2006) Film kreativ: Aktuelle Beiträge zur Filmbildung (Medienpädagogik interdisziplinär 6). München: Kopaed.

Paech, J. (1974) 'Kritik der praktischen Medienarbeit'. In Schwarz, R. (ed.) Manipulation durch Massenmedien - Aufklärung durch Schule? Eine Bestandsaufnahme (Didaktik der Massenkommunikation 1). Stuttgart: Metzler, 211-37

Paech, A. (1989) 'Die Schule der Zuschauer: Zur Geschichte der deutschen Filmclub-Bewegung'. In Hoffmann, H. and Schobert, W. (eds) Zwischen Gestern und Morgen: Westdeutscher Nachkriegsfilm, 1946-1962. Frankfurt am Main: Deutsches Filmmuseum, 226-46.

Pauleit, W. (2009) 'Film als Handlungsfeld: Oder: Wie "falsches Spiel" zu Bildungsprozessen führt'. In Henzler, B. and Pauleit, W. (eds) Filme sehen, Kino verstehen: Methoden der Filmvermittlung. Marburg: Schüren, 118-36.

Reichwein, A. (1967) Film in der Schule: Vom Schauen zum Gestalten. Braunschweig: Westermann.

Richtmeyer, U. (2009) Kants Ästhetik im Zeitalter der Photographie: Analysen zwischen Sprache und Bild. Bielefeld: Transcript.

Schädler, S. (2008) Wenn Derrida Schneewittchen trifft... Filmpädagogik und (Dekonstruktion) von Geschlechterklischees. München: Kopaed.

Schlüpmann, H. (2004) ,Kino und Schule'. In Pauleit, W. (ed.) Ästhetische Erziehung im Medienzeitalter (Ästhetik und Kommunikation 125). Berlin: Ästhetik und Kommunikation, 25-32.

Schorb, B. (1995) Medienalltag und Handeln: Medienpädagogik in Spiegel von Geschichte, Forschung und Praxis. Opladen: Leske + Budrich.

Schorb, B. (2009) 'Gebildet und kompetent: Medienbildung statt Medienkompetenz?'. Medien und Erziehung, 53 (5), 50-6.

Spanhel, D. (2010) 'Medienbildung statt Medienkompetenz? Zum Beitrag von Bernd Schorb'. Medien und Erziehung, 54 (1), 49-54.

Strobel, H. (1993) 'Kinderfilm und Kinderkino in der BR Deutschland'. In Twele, H. (ed.) Kinderkino in Europa. Frankfurt am Main: Bundesverband Jugend und Film, 9-16.

Vision Kino (2018a) 'Filmhefte'. Online. www.visionkino.de/publikationen/filmhefte/ (accessed 24 January 2018).

Vision Kino (2018b) 'Film im Lehrplan'. Online. www.visionkino.de/lehrplan-ausbildung/film-imlehrplan/ (accessed 24 January 2018).

Vision Kino (2018c) 'SchulKinoWochen'. Online. www.visionkino.de/WebObjects/VisionKino.woa/ wa/CMSshow/1056144 (accessed 24 January 2018).

Zahn, M. (2012) Ästhetische Film-Bildung: Studien zur Materialität und Medialität filmischer Bildungsprozesse. Bielefeld: Transcript. 